\title{
Recent Development of the Intellectual Property Rights System in China and Challenges Ahead
}

\author{
Can Huang \\ Zhejiang University, China
}

\section{INTRODUGTION}

As Peng, Ahlstrom, Carraher, and Shi (2017) rightly noted, Intellectual Property Rights (IPR) protection in a country is not static. It evolves over time. Peng et al. (this issue) revealed through their historical analysis that during the $19^{\text {th }}$ century, the US was not a leading IPR advocate but a leading IPR violator. It was only when indigenous inventors, authors, and organizations of the US emerged and demanded protection of their IPR in foreign countries in the late $19^{\text {th }}$ century that the US passed the International Copyright Act (the Chace Act) in 1891 to extend IPR protection to foreign works. The US case illustrated that a country's IPR system as an institution evolves as its economy and society develop. If we examine this evolution over a relatively long time span, the change can be quite dramatic. Therefore, when reviewing a country's IPR system, an important question to be asked is in which direction the country's IPR system evolves.

In this commentary, I aim to join the debate on IPR protection in China. I provide factual and statistical evidence to support Peng et al.'s (2017) prediction that China can be expected to voluntarily enhance its IPR protection. I also offer a nuanced account of the cause of the recent patenting surge in China and document the most recent development of judicial and legislative efforts regarding IPR protection in China, shedding light on the path on which China is moving forward.

\section{GHINA HAS A YOUNG BUT DYNAMIC IPR SYSTEM}

The Venetian Patent Statue of 1474, established in the Republic of Venice, is deemed to have been the first statutory patent system in Europe and the earliest codified patent system in the World (European Patent Office, 2009; Ladas, 1975). In 1624, English Parliament adopted the Statute of Monopolies, declaring all monopolies granted by the Crown to be void except those based on patents for 
Table 1. Law and regulation of the Chinese IP system

\begin{tabular}{ll}
\hline \hline Law or Regulation & Date of Coming into Force \\
\hline Trademark Law & March 1, 1983 \\
Patent Law & April 1, 1985 \\
Copyright Law & June 1, 1991 \\
Regulations on Protection of Computer Software & October 1, 1991 \\
Anti-unfair Competition Law & December 1, 1993 \\
Regulations on Administration of Audio-Visual Products & October 1, 1994 \\
Regulations on the Customs Protection of Intellectual Property Rights & October 1, 1995 \\
Regulations on the Protection of New Varieties of Plants & October 1, 1997 \\
Regulations on Protection of Integrated Circuit Layout Design & October 1, 2001 \\
Measures for the Administrative Protection of Internet Copyright & May 30, 2005 \\
\hline \hline
\end{tabular}

Source: Author's compilation.

inventions. Some important inventions during the Industrial Revolution, including James Watt's radically improved steam engine, were granted patents. The US constitution, which came into force in 1789, states in Article I, Section 8, Clause 8 '(the Congress shall have power) to promote the progress of science and useful arts, by securing for limited times to authors and inventors the exclusive right to their respective writings and discoveries'. This article authorized the US patent law.

Compared with the above-mentioned industrialized countries, such as Italy, the UK, and the US, which have several centuries of history of developing IPR protection, China has a young IPR system and only four decades of experience with using and protecting IPR. As seen in Table 1, in the 1980s and the early 1990s, China enacted and promulgated the Trademark Law, Patent Law and Copyright Law, laying the foundation for a modern IPR system. The establishment of the modern Chinese IPR system was necessitated by the opening up of the Chinese economy in late 1970s, and the need for attracting foreign direct investment and fulfilling the obligation stipulated in the bilateral agreements between the Chinese government and foreign governments on cooperation in science and technology. An example of the bilateral agreements is the China-US Agreement on Cooperation in Science and Technology signed in 1979 by then Chinese Premier Deng Xiaoping and US President Carter (State Intellectual Property Office, 2016: 78).

Subsequently, in the 1990s, China promulgated the Regulations on the Protection of Computer Software, Anti-unfair Competition Law, Regulations on Administration of Audio-Visual Products, Regulations on Customs Protection of Intellectual Property Rights, and Regulations on Protection of New Varieties of Plants. In the 2000s, China further enacted the Regulations on the Protection of Integrated Circuit Layout Design and Measures for the Administrative Protection of Internet Copyright.

To complement the establishment and development of the institutional legal system comprising the domestic law, China also joined international treaties 
regulating Intellectual Property (IP) matters. China became a member of the World Intellectual Property Organization in 1980, joined the Paris Convention for the Protection of Industrial Property in 1985, the Madrid Agreement Concerning the International Registration of Marks in 1989, the Berne Convention for the Protection of Literary and Artistic Works in 1992, the Convention for the Protection of Procedures of Phonograms Against Unauthorized Duplication of Their Phonograms in 1993, the Patent Cooperation Treaty in 1994, and the WIPO Copyright Treaty in 2007. Joining these international treaties, China recognized the principles established by the treaties and accepted its rights and obligations associated with the contracting countries of the treaties, adopting the international legal framework related to IP matters.

China's IPR system is young but dynamic. China has amended its Patent Law three times in the past three decades, and the fourth amendment is around the corner (Lloyd, 2016). Table 2 demonstrates that the overall trend of amendments to Chinese Patent Law is to strengthen patent protection and improve patent quality. For example, the statutory damage in a range from RMB 5,000 to 1,000,000 was introduced in the third amendment of the Patent Law for cases in which the loss of the plaintiff (patent owner), income of defendant (alleged infringer), and royalties are difficult to be determined. The range of the statutory damage was increased from RMB 100,000 to 5,000,000 in the draft of the fourth amendment of the Patent Law, which was published in December 2015. In the draft, the punitive damage was introduced, which can be up to three times the loss sustained by the plaintiff. In addition, a 'reversing burden of proof' mechanism, similar to that in the Trademark Law, was designed. In the draft of the Law, it is stated that after an infringement is concluded, if the plaintiff tries their best to collect evidence of damages, a court can shift the burden of proof to order the defendant to provide evidence such as account books. This clause aims to ease the difficulty in collecting infringement evidence due to the current Patent Law.

The first revision of the Patent Law in 1993 was to fulfill the commitment that China made in the negotiation to join the General Agreement on Tariffs and Trade, which was later superseded by the World Trade Organization in 1995, and in the negotiation with the US, to sign the 'Memorandum of the Chinese and US Governments on Protecting the Intellectual Property' (State Intellectual Property Office, 2008a). The second amendment was to align the Chinese patent law with the international standard in anticipation of signing, in 2001, the Agreement on Trade-Related Aspects of Intellectual Property Rights as part of the World Trade Organization obligations. However, different from the first two revisions, the third amendment of the Patent Law was triggered by the call from the stakeholders in the Chinese patent system, including domestic and foreign companies, universities and research institutes to strengthen patent protection. It was also an important action item outlined in the National IP Strategy, set by the Chinese government to promote indigenous innovation and establish an innovative economy (State Intellectual Property Office, 2008b). Similarly, the fourth amendment, starting in 
Table 2. Amendments of the Chinese Patent Law

\begin{tabular}{|c|c|c|}
\hline Amendment & Date of Coming into Force & (Proposed) Major Changes \\
\hline $1^{\text {st }}$ amendment & January 1, 1993 & $\begin{array}{l}\text { Expand patentable subjects; extend the protection } \\
\text { period of invention patents to } 20 \text { years, that of } \\
\text { utility models to } 8 \text { years and that of designs to } \\
10 \text { years; strengthen patent protection. }\end{array}$ \\
\hline $2^{\text {nd }}$ amendment & July 1, 2001 & $\begin{array}{l}\text { Amend China's patent law in line with the } \\
\text { international standard, as China anticipated } \\
\text { signing the Agreement on Trade-Related } \\
\text { Aspects of Intellectual Property Rights as part } \\
\text { of its World Trade Organization obligations in } \\
2001 \text {. }\end{array}$ \\
\hline $3^{\text {rd }}$ amendment & October 1, 2009 & $\begin{array}{l}\text { Improve patent quality (introduction of absolute } \\
\text { novelty standard), better protect national } \\
\text { security interests through confidentiality } \\
\text { examination; improve the design of the patent } \\
\text { system, promote the usage of patents, } \\
\text { strengthen the enforcement of patent rights; } \\
\text { better balance between patent protection and } \\
\text { the public interest. }\end{array}$ \\
\hline $\begin{array}{c}\text { Forthcoming } 4^{\text {th }} \\
\text { amendment }\end{array}$ & $\begin{array}{l}\text { A draft was published } \\
\text { in December } 2015 \\
\text { to collect comments } \\
\text { from the general } \\
\text { public }\end{array}$ & $\begin{array}{l}\text { Strengthen patent protection, solving the problem } \\
\text { of "difficulty in collecting infringement } \\
\text { evidence, long legal and administrative } \\
\text { procedure, low awarded damage, high cost and } \\
\text { low effectiveness of enforcement"; facilitate } \\
\text { usage of patent and technology transfer; clarify } \\
\text { and improve the role of the government in } \\
\text { enforcement, providing public service and } \\
\text { facilitating the usage of patents; improve the } \\
\text { application review process and improve the } \\
\text { quality of patents; improve the service provided } \\
\text { by the patent agency and nurture the } \\
\text { development of the IP service sector. }\end{array}$ \\
\hline
\end{tabular}

Source: Author's compilation.

2011, was a self-initiated legislative effort to better the patent system and further strengthen IPR protection. The amendments of the Patent Law in China support Peng's et al. (2017) prediction that China would voluntarily enhance its IPR protection as its economy became sufficiently innovation-driven, just as the US did in the past.

As important as the legislative progress is, indigenous industry also plays an active role in improving IPR protection in China. In the past, Chinese video websites were full of low-quality and unlicensed content. However, as indigenous Internet companies developed in the past decade, the major online video websites all offer licensed video content through advertising and subscription-based services. As these companies invested heavily in licensing from content providers, they also established rigorous enforcement strategies through litigation and takedown mechanisms. Similar changes occurred in the online music area (Irvin, 2016). 


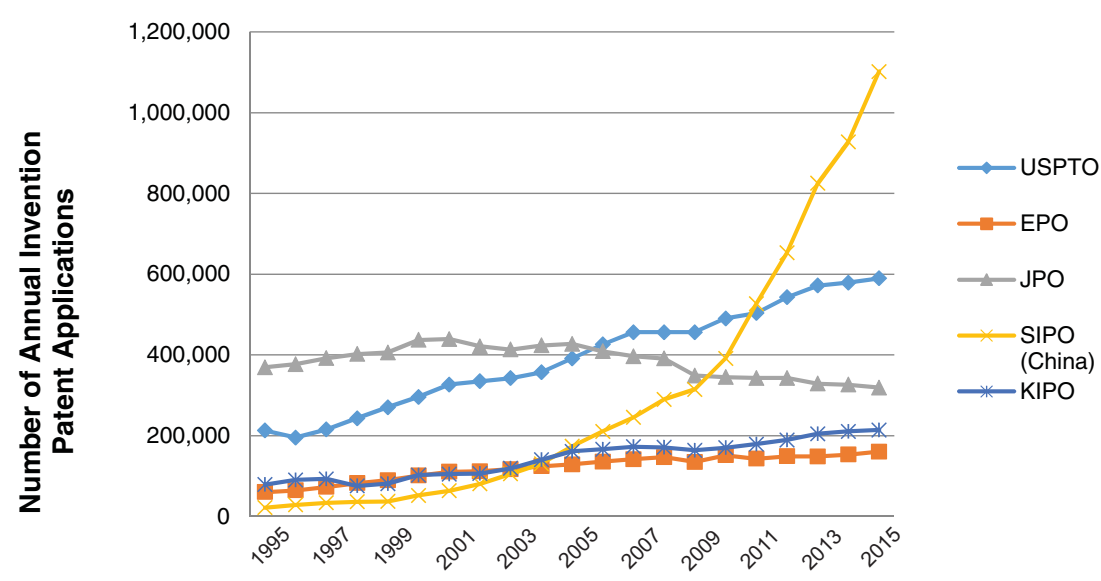

Figure 1. Number of annual invention patent applications filed in the US Patent and Trademark Office (USPTO), European Patent Office (EPO), Japanese Patent Office (JPO), State Intellectual Property Office of China (SIPO) and Korean Intellectual Patent Office (KIPO)

Source: Author's compilation.

In the US, more than 100 years passed between authorizing the patent law in the constitution in 1789 but denying protection to foreign intellectual property and passing the International Copyright Act in 1891 to extend protection to foreign works. However, it took less than three decades for China between enacting the Patent Law and voluntarily amending it to strengthen protection and further stimulate innovation. Even with the criticism over the imperfection of current IPR protection in China, one cannot deny that China has made rapid progress in developing the IPR system since its establishment.

\section{REGENT PATENTING SURGE IN GHINA AND ITS GONTROVERSY}

As Peng et al. (2017) also mentioned, China has witnessed a patenting surge over the past 15 years. As demonstrated in Figure 1, the number of invention patent applications received by the State Intellectual Property Office of China (SIPO) increased from 63,000 in 2001 to 1.1 million in 2015, representing a staggering 17 fold increase. China surpassed the US in 2011 to become the country receiving the most invention patent applications in the world. Even when the invention patent applications filed in the SIPO amounted to 928,000 in 2014, the number still increased nearly $20 \%$ to reach 1.1 million in 2015. The surge has also occurred in China's overseas patent filing. Figure 2 shows that China surpassed Germany in 2013 to become the third largest Patent Cooperation Treaty (PCT) patent application filing country only after the US and Japan and has further closed the gap with these two countries since then. As the PCT filing route is one of the two routes filing applications overseas (the other is Paris Convention route), the statistics of China's PCT patent applications demonstrate the rapid growth of Chinese entities' applications in foreign countries. 


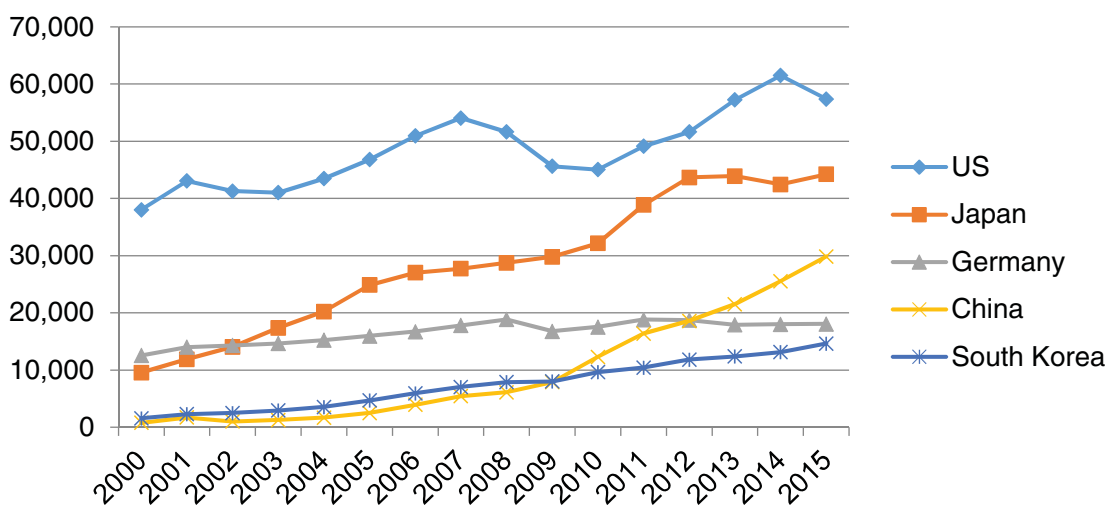

Figure 2. World Intellectual Property Organization-administered Patent Cooperation Treaty (PCT) Patent Applications: Top five countries

Source: Author's compilation.

The pro-patent amendments of the Chinese Patent Law are an important reason for the patenting surge in China. Hu and Jefferson (2008) argued that the other reasons include the intensification of $\mathrm{R} \& \mathrm{D}$ of the Chinese economy, which results in more patentable technologies. The vast inflow of foreign direct investment to China provided opportunities to domestic firms to imitate and incentivized them to apply for patents to compete with foreign firms. As the economic reform in China deepened, many state-owned enterprises were privatized. The private firms protected their intellectual property more aggressively than the state-owned firms.

$\mathrm{Li}$ (2012) argued that the introduction of the patent application subsidy adds another explanation for the patenting surge in China. The patent subsidy programs implemented by the provincial governments incentivize not only firms, universities, and research institutes but also individuals to apply for patents. The programs subsidize patent filing and patent renewal fees but do not discriminate between different technologies. The central government also runs a patent subsidy program. In 2009, the Ministry of Finance, on behalf of the central government, established a program to subsidize overseas patent applications, but the companies, universities or research institutes had to apply for the subsidy through the provincial IP offices (Ministry of Finance, 2012).

The patent subsidy programs are controversial and have received criticism. Liu, Liu, and Huang (2016) argued that the programs induced junk patents, which may not have been applied for without the subsidy. Dang and Motohashi (2015) provided empirical evidence that patent subsidy policy caused the $30 \%$ increase in patent applications that a typical firm in their sample would apply for and induced the firms to narrow the claims to obtain a greater number of patents, which, in other words, decreased the quality of the patents.

The motivation of the provincial governments to subsidize patent applications reached its apex as the 'number of invention patents per ten thousand inhabitants' was specifically listed, for the first time, as one of the 24 indicators in the $12^{\text {th }}$ 
Five-Year Plan in 2011 to measure China's economic and social development. The governments did not spare their efforts to boost the patent applications from their municipalities or provinces to meet the target set by the central government in the $12^{\text {th }}$ Five-Year Plan. The enthusiasm for the provincial governments to further subsidize and reward patent applications is not expected to ebb, as the same indicator continues to be included in the $13^{\text {th }}$ Five-Year Plan for the $2016-2020$ period.

Patent subsidies are only one instrument of the system of policy incentives to spur patent applications in China (Cheng \& Huang, 2016). The other instruments include patent remuneration that outstanding inventors and workers are eligible to receive for patent application projects and preferential tax treatment that allow the companies owning IP of their indigenous technologies to pay income tax at the rate of $15 \%$ versus the regular tax rate of $25 \%$. All these incentives contributed to a system rewarding the quantity of patenting over the quality. The system runs a risk of squandering scarce public financial resources to sponsor the acquisition of private rights, and many of these rights are valueless because they would not be acquired without subsidies. The Chinese government realized the problem and pledged to address it by improving the quality of patents (State Council, 2015), but this is still work in progress.

\section{REGENT JUDICIAL AND LEGISLATIVE EFFORTS IN IPR PROTEGTION}

China established three specialized IP courts in Beijing, Shanghai, and Guangzhou at the end of 2014 to enhance the effectiveness and efficiency of the judicial system of IPR protection. This marks as an important step of the Chinese government to strengthen the enforcement of IPR protection. Because IP laws and technology can be complex, having cases decided by experienced judges in specialized IP courts can increase the quality and the speed of the decisions and achieve greater consistency. In addition, specialized IP courts can provide better training for judges and produce more knowledgeable judges who are familiar with technical patent matters. A recent study by the IP House (2016) on the cases processed by the Beijing Intellectual Property Court in 2015 found that the average awarded damages were RMB 460,000, representing a large increase from the RMB 80,000 previously reported in the SIPO-commissioned study (Intellectual Property Research Center, 2012). It is also reported that on average each of the 18 judges in the Court made decisions for 239 cases in 2015, three times the number of the cases for which the judges were able to decide previously in the Beijing Intermediate Court in 2014 (Hu, 2016). This preliminary evidence all points to an improvement in the effectiveness and efficiency achieved by the specialized IP court.

In terms of legislative efforts, China amended the Law on Promoting the Transformation of Scientific and Technological Achievements in October 2015, which was an important step in removing the barriers for technology transfer in 
China. In 2015, the State Council Legislative Affairs Office published drafts for two important pieces of legislation regarding IPR protection for public opinion consultation. One is the fourth amendment of the Patent Law, which is discussed above. The other is Service Invention Regulations discussed below.

The twenty years of rapid economic and social development in China since the Law on Promoting the Transformation of Scientific and Technological Achievements came into force in 1996 have made the Law outdated. Under this Law, universities and public research organizations in China did not possess full authority on matters involving technology transfer. They had to obtain approval from government agencies to transfer the technologies developed by their researchers. When selling patents, they were not allowed to negotiate the price with buyers. Instead, the patents had to be listed in the property markets for auction, and a tedious procedure had to be followed to sell them. In practice, few companies would wait for the long process to buy patents from universities or public research organizations. Most companies would choose to obtain exclusive licensing instead. In addition, universities and public research organizations were not allowed to keep the revenue from technology transfer but were required to transfer such income to government agencies. These regulations became obstacles for technology transfer.

The amendment of the Law came into force on October 1, 2016. The new Law has made progress in four aspects, as follows: 1) It requires scientific and technological achievements, including new technologies and patents, to be disclosed to public. 2) It incentivizes universities and public research organizations to transfer technology. The Law stipulates that the revenue from the technology transfer can be retained by universities and public research organizations. No approval from the government is needed. Not less than $20 \%$ of the revenue from technology transfer should be shared with inventors of technologies as compensation. Price negotiation is allowed for patent sale in addition to auction. 3) It supports companies to play an active role in technology transfer. 4) It stipulates that government organizations should improve their service to assist technology transfer activities.

The draft of the Service Invention Regulations, which was published in April 2015, represents new legislation to provide provisions regarding the ownership of service inventions, the service invention reporting system, and the reward and remuneration system for the employee-inventor. The motivation for enacting such a regulation is that although the current Patent Law of China and its Implementing Rules and other relevant laws and regulations already provide provisions for the service invention system, it is not uncommon to find that actual inventors are not acknowledged in patent applications. Award to service invention is not guaranteed. A services invention reporting system has yet to be established in many organizations, which can give rise to disputes. In addition, procedures for solving disputes are not clear.

In the Draft Regulations, agreements resulting from negotiation between employer and employee regarding ownership of and award and compensation to 
service invention is allowed and protected. It also calls for employers to establish an internal reporting system to allow inventors to report inventions and apply for IPR, and a system for rewarding and remunerating its employee inventors. Intellectual property, science and technology and human resource departments of governments jointly supervise the enforcement of service invention regulation. Disputes can be solved in administrative or legal channels.

\section{GONGLUSION}

The Chinese government announced the 'innovation-driven' development strategy to promote the economic and social development of the country in the 18th National Congress of the Communist Party of China in 2012. However, China faces a number of serious challenges in implementing the strategy. One of them is that IPR protection is inadequate and infringement is rampant (Lewin, Murmann, \& Kenney, 2016; State Council, 2015; World Economic Forum, 2016). The Chinese government acknowledged this problem and pledged to implement 'more stringent IPR protection' (State Council, 2015). The amendments to the Patent Law, the draft of the Service Invention Regulations and the establishment of the specialized IP courts revealed that the Chinese government is indeed making serious efforts in the promised direction. It is equally important that the indigenous inventors, universities and research organizations and industries in China, as stakeholders of the innovation system, demand more stringent IP protection and enforce the protection more rigorously themselves. As Peng et al. (2017) argued, China could follow (and is following) the path that the US has taken, to move from a country with weak IPR protection to become a country with effective IPR protection.

\section{NOTE}

I am grateful to the Editor-in-Chief, Professor Arie Lewin, for the invitation to prepare this commentary. The work is supported by the National Natural Science Foundation of China, Grant No. 71402161 .

\section{REFERENGES}

Cheng, M. L., \& Huang, C. 2016. Transforming China's IP system to stimulate innovation. In A. Y. Lewin, M. Kenney, \& J. P. Murmann (Eds.), China's innovation challenge: Overcoming the middle-income trap: 152-188. Cambridge: Cambridge University Press.

Dang, J., \& Motohashi, K. 2015. Patent statistics: A good indicator for innovation in China? Patent subsidy program impacts on patent quality. China Economic Revieze, 35: 137-155.

European Patent Office, 2009. Patent Teaching Kit.

Hu, A. G., \& Jefferson, G. H. 2009. A great wall of patents: What is behind China's recent patent explosion? Journal of Development Economics, 90(1): 57-68.

$\mathrm{Hu}, \mathrm{H}$. 2016. The reform in the Beijing intellectual property court is effective. China Radio International. [Cited 15 November 2016]. Available from URL: http://news.cri.cn/201634/ 9ee5108c-9e43-91c0-74d8-328018bc2dde.html 
Intellectual Property Research Center. 2012. Report on Empirical Study on the Damage Awarded in the IP-infringement Cases. Zhongnan University of Economics and Law.

IP House. 2016. The report on judicial protection from Beijing intellectual property court 2015. [Cited 15 November 2016]. Available from URL: http://www.iphouse.com.cn/pdfdata/ iphouse_2015.pdf

Irvin, B. 2016. The view on Chinas IP environment from inside a Chinese corporation. Intellectual Asset Management, 77: 83-85.

Ladas, S. P. 1975. Patents, trademarks, and related rights: National and international protection. Cambridge, MA: Harvard University Press.

Lewin, A. Y., Kenney, M., \& Murmann, J. P. (Eds.). 2016. China's innovation challenge: Overcoming the middle-income trap. Cambridge, UK: Cambridge University Press.

$\mathrm{Li}, \mathrm{X} .2012$. Behind the recent surge of Chinese patenting: An institutional view. Research Policy, 41(1): 236-249.

Liu, K.-C., Liu, C., \& Huang, J. 2016. IPRs in China-market-oriented innovation or policy-induced rent-seeking? In K.-C. Liu \& R. Uday (Eds.), Innovation and IPRs in China and India, myths, realities and opportunities: 161-179. Singapore: Springer.

Lloyd, R. 2016. A new world order. Intellectual Asset Management, 76: 29-35.

Ministry of Finance. 2012. Regulation on the special fund to subsidize overseas patent filing. [Cited 2 November 2016]. Available from URL: http://jjs.mof.gov.cn/zhengwuxinxi/zhengcefagui/ 201205/t20120531_655657.html

Peng, M. W., Ahlstrom, D., Carraher, S. M., \& Shi, W. S. 2017. How history can inform the debate over intellectual property. Management and Organization Revieze, 13(1): in press.

State Council. 2015. Opinions of the state council on accelerating building up the intellectual property strong country under the new situation. [Cited 15 November 2016]. Available from URL: http://www.gov.cn/zhengce/content/2015-12/22/content_10468.htm

State Intellectual Property Office. 2008a. The background and content of the first two amendments of the patent law. [Cited 15 November 2016]. Available from URL: http://www.sipo.gov.cn/ zxft/zlfdscxg/bjzl/200804/t20080419_383845.html

State Intellectual Property Office. 2008b. The background of the third amendment of the patent law. [Cited 15 November 2016]. Available from URL: http://www.sipo.gov.cn/zxft/zlfdscxg/bjzl/ 200804/t20080419_383848.html

State Intellectual Property Office. 2016. Intervieze with the retired officers of the state intellectual property office. Intellectual Property Publishing House.

World Economic Forum. 2016. China's innovation ecosystem. 